\title{
Társadalmi innováció a turizmus kontextusában
}

\author{
Szerzők: Michalkó Gábor ${ }^{1}$ - Kenesei Zsófia² K Kiss Kornélia $^{3}$ \\ - Kolos Krisztina ${ }^{4}$ - Kovács Edina ${ }^{5}$ Pinke-Sziva Ivett $^{6}$
}

Az állam a szabadidőipar kínálta szolgáltatások közül különösen a turizmushoz való hozzáférés legkülönbözőbb eszközökkel történô biztositásával igyekszik a társadalom életminőségét kedvezôen befolyásolni. Annak ellenére, hogy a turisztikai kínálat fogyasztásában érintettek köre egyre tágul, továbbra is tekintélyes a nem utazó háztartásokban élók száma. Mivel a turizmusból való kimaradás hátterében gyakran nem anyagi természetú tényezôk húzódnak meg, magának a társadalomnak kell a szabadidő utazással való eltöltését gátló tényezőkkel szembenéznie, megoldást találnia a turizmus depriváltjainak felkarolására. Természetesen a turizmusipar nem csak az utazó, hanem a szolgáltató szerepkörében is képes az életminóséget növeló aktivitások biztositására, melyhez elsôsorban az érintett közösség - empátiára, kreativitásra és összefogásra épülő - innovációjára van szükség. A jelen tanulmány arra a kérdésre keresi a választ, hogy a turizmus és a társadalmi innováció szimbiózisával kapcsolatos hazai és nemzetközi szakirodalmi előzmények mennyiben képesek megalapozni, illetve elősegíteni egy jövőbeli, nagyszabású vizsgálat lefolytatását. Az elvégzett irodalomelemzés eredményei egyrészt igazolták, hogy sikerült egy nemzetközi kitekintésben is fehér foltnak számító problémára fókuszálni, másrészt elóre vetítik, hogy a témában az öregedés, a szegénység és az akadálymentesség képezi a legfontosabb kontextuális pilléreket.

Kulcsszavak: társadalmi innováció, turizmus, irodalomelemzés, depriváció.

\section{Bevezetés}

Miközben a társadalmak szabadidő-felhasználásának sajátosságait hosszú évszázadokon keresztül az érintett közösségek kohéziója, együttmúködési készsége, egymás ötleteit plántáló kreativitása befolyásolta (PIRENNE 1983, DUBY 1984), az ipari forradalmak korától nyomon követhetó technikai és technológiai fejlődésnek köszönhetôen (LANDES 1986) a szabadidő eltöltése alapvetően a folyamatosan bővülő kínálathoz való egyéni igazodás függvényévé vált. A XX. század második felére a szabadidő-eltöltés mint eredendően örömteli közösségi létforma - a szabadidőipar globális szolgáltatássá válásával párhuzamosan - individualizálódott, amely jelenség kedvezőtlenül hatott a kínálat elérhetőségét tekintve bármilyen oknál fogva korlátozottak (depriváltak) szubjektív életminőségére

\footnotetext{
'egyetemi tanár, Budapesti Corvinus Egyetem; tudományos tanácsadó MTA CSFK Földrajztudományi Intézet, gabor.michalko@uni-corvinus.hu ${ }^{2}$ egyetemi tanár, Budapesti Corvinus Egyetem, zsofia.kenesei@uni-corvinus.hu ${ }^{3}$ egyetemi docens, Budapesti Corvinus Egyetem, kornelia.kiss@uni-corvinus.hu ${ }^{4}$ egyetemi tanár, Budapesti Corvinus Egyetem, krisztina.kolos@uni-corvinus.hu ${ }^{5}$ PhD-hallgató, Budapesti Corvinus Egyetem, edina.kovacs@uni-corvinus.hu ${ }^{6}$ egyetemi docens, Budapesti Corvinus Egyetem, ivett.sziva@uni-corvinus.hu
}

(a kívülállás tudatosulása akár a lelkiállapot romlását is előidézheti). Amíg a rendszeresen ismétlődő eseményekhez kötődő társas együttlét (bál, búcsú, majális, vásár, valamint különféle szerveződésú csoportok rendezvényei) még egy-két generációval korábban is a szabadidő-felhasználás legfontosabb attribútumát jelentette, mára a múszaki környezetünk feltartóztathatatlan innovációja jelentôs mértékben erodálta a közösségekben rejlő erőforrásokat (KISS 2013). A (poszt)modern szabadidőipar vívmányaiból kiszorulók kompenzálására az egyre sokrétúbb felelősségvállalásra kényszerülő állam hivatott, de a társadalom évszázados feladatköreinek (például gondoskodás, közösségi élmény nyújtása) teljes átvételét nem tudja megoldani. Az állam érdeke a társadalom életminőségének növelését eredményező innovációk szorgalmazása, de a munka világával szimbiózisban élő szabadidős szféra individualizációjából fakadó kihívásokkal gyakran maguknak az érintett közösségeknek kell megbirkózniuk.

A szabadidő-orientált utazások XIX. század közepétől megjelenő szervezettsége, az átmeneti környezetváltozással összefüggó élményszerzést biztosító szolgáltatások piaci termékké formálása a turizmust a szabadidő-eltöltés alternatívájává, az életminóséget befolyásoló tényezóvé tette (MICHALKÓ 2012, SMITH - DIEKMANN 2017). 
Lektorált tanulmányok

Napjainkra a turizmus megkérdőjelezhetetlenül a fejlett társadalmak létformájává avanzsált, az egyének szokásos térpályáin túli utazásai mind a szabadság eltöltésében, mind a munka világában mindennapos aktivitássá váltak, és 2016-ban világszinten már közel 1,3 milliárd nemzetközi turistaérkezést eredményeztek (UNWTO 2017). A turizmus fejlódéstörténetében az innovációk kulcsfontosságú szerepet töltöttek be, számos technikai, technológiai fejlesztés (például a sugárhajtású utasszállító repülógépek, vagy a számítógépes foglalási rendszerek elterjedése) a növekedés mérföldköveként értelmezhető (PUCZKÓ - RÁTZ 1998). Ugyan a turizmusban közvetlenül vagy közvetve érdekelt cégek innovációi elsősorban profitorientáltak, mégis hozzájárulnak a társadalom életminőségének növekedéséhez (KISS 2015). $\mathrm{Az}$ állam egyrészt érdekelt a jövedelemtermeló, munkahelyteremtő turisztikai vállalkozások innovatív törekvéseinek legkülönbözőbb eszközökkel történó támogatásában, másrészt a turizmusipar kínálta bóvülő szabadidős aktivitásokból kiszorulók számának csökkentésében (BEHRINGER et al. 2002). Felismerve a turizmus életminőségre gyakorolt kedvező hatásait, az állam - a technikai, technológiai innovációk eredményezte fejlődés piacgazdasági következményeit kompenzálandó - elsősorban a belföldi turizmus vonatkozásában igyekszik a szolgáltatásokhoz szélesebb körú társadalmi hozzáférést biztosítani (PUCZKÓ - RÁTZ 2011). Tekintettel arra, hogy a turizmusból való kimaradás okai nem minden esetben anyagi természetúek (KSH 2016), egyes esetekben magának a társadalomnak kell megoldást találnia a szabadidó utazással való eltöltésének lehetővé tételére.

Nem szabad figyelmen kívül hagyni, hogy az utazás világából történő, életminôség-romlást eredményező kiszorulás a turista és a szolgáltató szerepkörében is bekövetkezhet, amely tartósan kedvezôtlen társadalmi pozícióból (szegénység, rokkantság stb.) vagy megváltozott élethelyzetból (gyermekvállalás, válás, nyugdíjba vonulás, leszázalékolás stb.), esetleg a környezet kihívásaira adott nem megfeleló válaszreakciókból (állásvesztés, piacvesztés, csőd stb.) is fakadhat. Az állam bármennyire is igyekszik a turizmus depriváltjainak felkarolására, látóköre, különösen annak mélysége korlátozott, erőforrásai végesek, így a szabadidó utazással való eltöltésében, illetve az egyén turisztikai szolgáltatóként történő piacra lépésében a társadalom kreativitásra, empátiára és összefogásra épülő innovációjára van szükség.

A jelen tanulmány arra a kérdésre keresi a választ, hogy melyek azok az eddigi kutatási eredményekre épüló szakirodalmi elózmények, amelyek a turizmus és a társadalmi innováció témakörében megfelelő teoretikus kiindulási alapot jelenthetnek egy tervezett, nagyobb volumenú magyarországi vizsgálat lefolytatásához. A tanulmány első felében a társadalmi innováció fogalomkörét járjuk körbe és tárjuk fel azokat a témaköröket, amelyek potenciális lehetóséget teremtenek a turizmussal kapcsolatos szimbiózisának megteremtésére, a második felében pedig egy 2017 októberében lebonyolított hibrid kutatás eredményeit mutatjuk be.

\section{Egy gumifogalom természetrajza}

A tudományos fogalomalkotás módszertana időtlen idők óta lázban tartja a filozófia, különösen a tudományfilozófia képviselőit (GADAMER 2003, HEIDEGGER 2007). Abban egyetértés mutatkozik, hogy egy új fogalom bevezetésére ritkán kerül sor légüres térben, akár a meglévő nomenklatúrából építkeznek a definitôrök, akár azok figyelmen kívül hagyásával, az eljárás akkor nevezhetố tudományosnak, ha az a megalapozottságra vonatkozó (szellemi) közösségi igényt elégít ki és rendszer szinten értelmezhető (THIEL 1976). Ezt támasztja alá MOKSONY (2002) véleménye is, miszerint egy megfigyelés csak akkor válhat fontos felismerések és újítások forrásává, ha a kutató képes a maga egyedi tapasztalatát általánosabb szabályszerúség megnyilvánulásaként szemlélni és ezt a tudományos közösség számára világosan kifejteni. Előfordul, azonban, hogy a fogalmak átlépik az alkotóik által megszabott kereteket, értelmezésük tágul, új és újabb jelentésekkel gazdagodik, amelyre eklatáns példaként szolgál az infrastruktúra kifejezéssel kapcsolatos asszociációk diverzifikáltsága (ABONYINÉ 2004). A tudományok közötti átjárhatóság (inter- és transzdiszciplinaritás) szorgalmazása, a tudományos ismeretterjesztés felértékelódése, továbbá a média tudományos eredmények iránti fokozott érdeklődése egyaránt hozzájárult az úgynevezett divatos szakkifejezések, kreatívan tágítható gumifogalmak (buzzword, fuzzword) kialakulásához (CAPOOR 2017). Akár a magyar, akár az angol nyelvú társadalomtudományi szakirodalmat vizsgáljuk, az erőforrás (resource), a fenntarthatóság (sustainability), a versenyképesség (competitiveness) vagy éppen a jelen tanulmány központi témáját képezó innováció (innovation) fogalmát górcső alá véve, ahány aspektusból közelítenek a szerzők, annyi féle értelmezésükkel, feltartóztathatatlan jelentésbővülésükkel találkozhatunk.

Joseph Schumpeter ${ }^{7}$ a "teremtő rombolás" elméletének kidolgozásával jelentősen hozzájárult a régi és az új kombinációk (gyakorlatok) viszonyá-

${ }^{7}$ Joseph Schumpeter (1883-1950), osztrák-amerikai közgazdász, osztrák pénzügyminiszter (1919-1920), a Harward professzora. 
nak, gazdasági, társadalmi funkciójának értékeléséhez, az innováció teoretikus kereteinek megalapozásához (BŐGEL 2008). Shumpeter az innováció öt altípusát különböztette meg, így termék-, folyamat-, piaci, beszerzési és szervezeti innovációról értekezett (PISKÓTI 2007). A megújulás folyamatát és annak eredményét egyaránt lefedô fogalom szoros szimbiózist alkot a versenyképességgel (CHIKÁN 2008). Az innováció alappillérét képező kreativitás egyéni, vállalati és nemzetgazdasági léptékben egyaránt növelheti a versenyképességet (SZILÁGYI 2006, BIRKNER - MÁHR 2016), amelynek eredője a társadalom életminóségében is megmutatkozik (SZIRMAI 2015).

A magyar folyóiratok tartalomjegyzékeinek kereshetó adatbázisában ${ }^{8}$ az innováció kifejezés összesen 1510 cikk címében szerepel' ${ }^{9}$. Ha csak az utóbbi idóben (2016-2017) megjelent cikkeket (155 db) vesszük górcső alá, az innováció fogalmának akkor is 26 eltérő kontextusú, illetve különbözô árnyalatú megközelítésével találkozhatunk. A „valamilyen" előtagú innovációk kavalkádjából jól kirajzolódik, hogy a társadalmi és környezeti vonatkozású innovációk állnak a közelmúltban magyar nyelven napvilágot látott folyóirat-cikkek középpontjában (1. ábra).

Az innováció fogalmi sokszínúsége a MATARKA adatbázisban lévő cikkek alapján

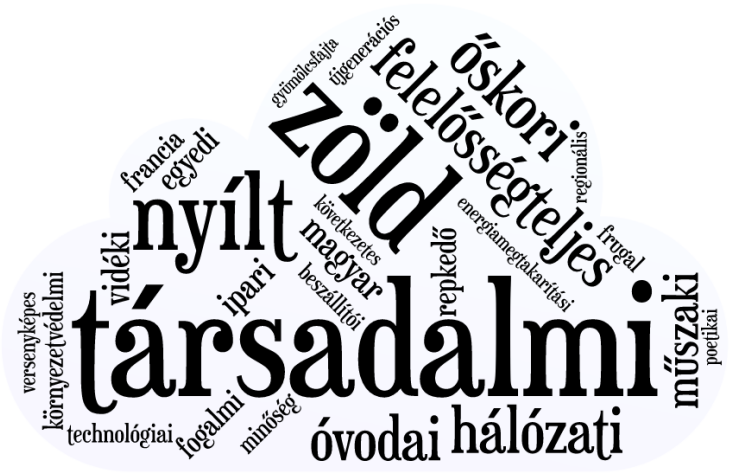

Forrás: saját adatgyüjtés a MATARKA adatbázisból

Az innováció fogalomfejlődésének elmúlt száz éve alatt számos tudományterület és részdiszciplína fejlődött az innováció-orientált gondolkodás talaján, melyek szakirodalma olyan tág, hogy már az összefoglaló áttekintések (literature review) is könyvtárnyi terjedelmúek, elemzésük meghaladná e tanulmány célkitúzését és terjedelmi korlátait.

\footnotetext{
${ }^{8}$ www.matarka.hu

${ }^{9}$ A keresés eredménye az adatbázis 2017. október 24-i állapotát tükrözi.
}

A társadalmi innováció kifejezés elterjedésében a Szociológusok Nemzetközi Szervezete ${ }^{10}$, különösen a társadalmi változásban jelentkező innovatív eljárásokkal foglalkozó munkacsoportja ${ }^{11}$, kitüntetett szerepet vállalt. 1974-ben a kanadai Torontóban megtartott tanácskozásukon szorgalmazták, hogy a társadalmi megújulással kapcsolatos folyamatok értelmezésének elősegítésére addig használatban lévó modernizáció kifejezést a semlegesebb konnotációjú innovációra cseréljék, ezzel egyidejúleg kutatási nézőpontjukban a jövőorientáltság kapjon hangsúlyosabb szerepet (HILL 1975). A technológiai változások társadalmi folyamatokra gyakorolt hatása, az adaptációból fakadó konzekvenciák és válaszok, valamint a fejlődés várható irányainak kijelölése már a társadalmi innovációval foglalkozó kutatások kezdeti idôszakában megjelentek a tanulmányok kulcsproblematikái között (GERSHUNY 1982). DRUCKER (1987) történeti perspektívába ágyazott esszéjében az egyén és a közösség kapcsolatán keresztül világít rá a tömegmozgalmak társadalomformáló szerepére és arra hívja fel a figyelmet, hogy a társadalmi innovációk gerjesztése a civil szférából kikerülve tudatosan irányított kezdeményezésekké válik.

POL és VILLE (2009) évtizedekkel a társadalmi innováció fogalmának felbukkanása és a tudományos kommunikációban bekövetkező diszkrét kanonizációja után megállapítják, hogy az akadémiai közösségek igen csak megosztottak a kifejezés tényleges tartalmi vonatkozásait illetóen, egyesek mindenre ráhúzható, homályos gumifogalomként, mások a társadalmi valóság megragadására alkalmas konstrukcióként értelmezik. A kritikai, ugyanakkor előremutató megközelítést alkalmazó szerzőpáros abból indult ki, hogy a társadalmi innovációnak valóban van egy olyan olvasata, miszerint a technológiai innovációra építő üzleti innováció hozadékaként jelenik meg és kibontakozásában a kormányzati beavatkozás katalizátor szerepet kap (példaként jelenítik meg az internet elterjedését, amely ugyan alapvetően profitorientált vállalkozások létrejöttét generálta, de közben a kommunikációban is forradalmi változásokat hozott, a hozzáférést pedig a legkülönbözőbb kormányzati projektek támogatják). POL és VILLE (2009) hangsúlyozzák, hogy mivel nem minden üzleti innováció jár társadalmi innovációval, illetve a társadalomra gyakorolt hatások nem minden esetben kedvezőek (lásd környezetszennyezés, drogfüggóség), ezért az annak részeként való értelmezése téves. A megértést elósegítendő bevezetnek egy új nézőpontot, az életminőséget, amely kulcsfogalommá válik a társadalmi innováció értelmezésében.

\footnotetext{
${ }^{10}$ International Sociological Association (ISA)

${ }^{11}$ Research Committee on Innovative Processes in Social Change
} 
Lektorált tanulmányok

Véleményük szerint azon ötletek tárháza, amelyek potenciálisan alkalmasak egy közösség életminőségének és életkilátásainak növelésére, kívánatos társadalmi innovációnak tekintendők, még akkor is, ha mindig lesznek olyanok, akiket a közjóként aposztrofált újítások hátrányosan érintenek. A kívánatos társadalmi innováció üzleti innovációtól történő megkülönböztetése arra vezethető vissza, hogy számos újitást, illetve kezdeményezést nem feltétlenül motivál a profit termelése.

A társadalmi innováció fogalmi elasztikusságára visszavezethetô értelmezési nehézségek jelentős akadályokat képeznek a vonatkozó kutatási eredmények széleskörú integrációjában (HAVE RUBALCAVA 2016). A szerzôpáros - a társadalmi innováció fogalmának az innovációval kapcsolatos kutatásokban való megjelenését elemezve - kiemeli, hogy a kifejezés legnagyobb dinamikájú elterjedése négy markáns területen detektálható: a közösségek pszichológiája (1), a kreativitás kutatás (2), a szociális és a társadalmi kihívások (3) és a helyi fejlesztések (4). A vezetéstudományban és a vállalkozásfejlesztés területén kezdeti fázisban vannak a társadalmi innováció orientált vizsgálatok. Mivel a társadalmi innováció egy viszonylag fiatal és kevésbé koherens, eklektikus konstrukció, amelyból különböző, multidiszciplináris szemléletú, együttgondolkodó közösségek alkotta megközelítések rajzolódnak ki, feltétlenül szükség van egy kompromisszumos definícióra. Ennek alapját a HAVE és RUBALCAVA (2016) által elvégzett vizsgálat a társadalmi kapcsolatokban (1) és az egyéni szükségletekkel, célokkal összefüggó, társadalmilag releváns problémákban (2) mint fogalmi pillérekben látja, ezekre épülve hozhatók létre az új társadalmi értékeket eredményező, korunk legkülönbözőbb kihívásaira (például öregedés, klímaváltozás) reagálni képes korszerú társadalmi technológiák. Ugyanakkor a definícióalkotás mellett, illetve éppen azt elősegítendô több nyitott kérdés megoldása is várat még magára, amelyek közül a politikai szféra szerepvállalása, a regionális eltérésekből fakadó technológiai különbségek áthidalása és a hasznosság jóléti vagy jólléti értelmezése tekinthető a szakirodalom alapján leginkább artikuláltnak.

\section{Tú a szénakazalban: egy pilot tartalomelemzés és annak tanulságai}

A szociológiai gyökerekkel rendelkező társadalmi innováció fogalmának mérsékelt ütemú terjedése, illetve a társtudományokba történó szolid beépülése tükröződik a turizmussal való szimbiózisában is. Transzdiszciplináris mivolta következtében a turizmusnak elvileg lakmuszpapírként kellene jeleznie a társadalmi innováció legkülönbözóbb kutatási kérdésekben való megjelenését, amelynek lenyomata a rendkívül problémagazdag turizmustudományi szakirodalomban lenne megragadható. A társadalmi innováció fogalomhasználatának a turizmussal foglalkozó vizsgálatok eredményeiben való megjelenését a kvalitatív és a kvantitatív kutatásmódszertan elegyítésére épülő tartalomelemzéssel tártuk fel (STEPCHENKOVA 2012).

Abból indultunk ki, hogy amennyiben a társadalmi innováció fogalma beszivárgott és valamilyen mértékben átitatta a turizmus gondolatvilágát, annak kézzelfogható nyoma lesz az egyik, méretében és presztízsében egyaránt jelentős online nemzetközi tudástárban, az Elsevier múködtette Sciencedirect felületén. Mivel az új fogalmak felbukkanásának elsődleges terepe a viszonylag gyors disszeminációt biztosító angol nyelvú folyóiratok univerzuma, ezért ezt a fórumot állítottuk a vizsgálatunk fókuszába.

1. táblázat

A társadalmi innováció és a turizmus szavak szimbiotikus tükrözódése a Sciencedirect adatbázisban (esetszámok, db)

\begin{tabular}{|c|c|c|c|}
\hline Keresett kifejezés & Cím & $\begin{array}{c}\text { Cím-kulcsszó- } \\
\text { absztrakt }\end{array}$ & $\begin{array}{c}\text { Teljes } \\
\text { szöveg }\end{array}$ \\
\hline social innovation & 50 & 150 & 1331 \\
\hline tourism & 6711 & 11694 & 61357 \\
\hline $\begin{array}{c}\text { social innovation AND } \\
\text { tourism }\end{array}$ & 0 & 0 & 150 \\
\hline
\end{tabular}

Forrás: www.sciencedirect.com (letöltve: 2017. október 12.)

A folyóiratokra szúkített adatbázis különféle szúrési feltételek beállítását tette lehetővé, így a cím, a cím-kulcsszó-absztrakt és a teljes szöveg képezte az egyes megfigyelési etapokat. Itt kell szólni a vizsgálat korlátairól is, amelyek az eredmények érvényességét befolyásolhatják. A különböző léptékú szúrések a cím, a kulcsszó és az absztrakt esetében meglehetósen pontos találatokat eredményeznek, azonban a folyóiratcikkek teljes szövegét monitorozó keresés már a kutatási kérdés megválaszolása szempontjából irreleváns információkra is kiterjed, mint például a hivatkozásjegyzék, a szerzók munkahelyi adatai vagy például kibóvített absztraktok esetében a konferencia elnevezése. Ezek a találatok (a tévesztésből fakadó „zaj” mellett) félrevezetően bóvítik az egyes kifejezések volumenét. Annak érdekében, hogy áttekintést kapjunk a turizmussal összefüggó problémák társadalmi innovációba való beágyazottságáról, a cikk cím, a kulcsszó és az absztraktban történó együttes előfordulás mellett az egyes cikkek azon szövegrészeit vettük górcsó 
alá, ahol a két kifejezés ugyanabban a gondolatkörben jelenik meg, illetve egyik vagy másik kifejezés a cikk cím, a kulcsszó és az absztrakt mellett a fó szövegben (beleértve a lábjegyzeteket) is szerepel.

A Sciencedirect adatbázis mindössze 50 olyan, angol nyelvú folyóiratcikket tartalmaz, amelynek címében szerepel a "social innovation" kifejezés, ugyanakkor 6711-et, amelyben a "tourism" szó (1. táblázat). Olyan közlemény, amelynek címében a "social innovation" és a "tourism" egyaránt szerepelnének nincs. A szimbiózis tekintetében hasonló kép tárul elénk, ha a kapcsolat keresését a kulcsszavakra és az absztraktra is kiterjesztjük. Ebben a kategóriában a "social innovation" kifejezés száma megháromszorozódik, a "tourism" pedig a kétszeresére nő, de a közös metszet továbbra is üres marad. Az elemzésre alkalmas adatbázis kialakítása szempontjából kizárólag a közlemények teljes szövegú pásztázása járt eredménnyel, mely esetben a kereső a kifejezések érdemi volumennövekedése mellett már 150 cikket kínált fel. Tekintettel arra, hogy az adatbázis képes a keresés eredményét relevancia szerint rendezni, továbbá vélelmezve, hogy az előre sorolt találatok elemzése (az ismétlódések miatt) elegendó a turizmus és a társadalmi innováció érzékelhetően szerény tudományos kapcsolatának körvonalazására, a teljeskörú vizsgálatot az első 50 cikkre végeztük el (a folyóiratokban megjelenő két darab könyvismertetést a redukált adattartalom miatt kivontuk az elemzésból).

A vizsgálatba vont 50-ból 32 olyan cikket találtunk, amelyeknél a címben, a kulcsszavak között vagy az absztraktban akár a "social innovation", akár a "tourism" kifejezések szerepelnek (azt a korábbiakban már megállapítottuk, hogy együttesen soha) és e mellett az eredményeket közló szövegrészben vagy az egyik vagy a másik, esetleg mindkettô szó megtalálható (függetlenül attól, hogy ugyanazon bekezdésben, illetve mondatban jelennek-e meg).

A turizmus és a társadalmi innováció kapcsolatának feltárása során azt is megvizsgáltuk, hogy milyen idóbeli intenzitással szerepelnek együttesen a Scimago adatbázis folyóirataiban a keresett kifejezések. A 2. táblázatban közreadott eredmények azt mutatják, hogy a találatok 63\%-a 2015-2017

2. táblázat

A társadalmi innováció és a turizmus szavak szimbiotikus tükrözódése a Sciencedirect adatbázisban szerepló folyóiratokban

\begin{tabular}{|c|c|c|}
\hline \multicolumn{3}{|c|}{ Idöbeli megoszlás } \\
\hline 2001-2007 & 2008-2014 & $2015-2017$ \\
\hline 5 & 7 & 20 \\
\hline \multicolumn{3}{|c|}{ Folyóirat szerinti megoszlás } \\
\hline \multicolumn{3}{|l|}{ Folyóirat } \\
\hline Megnevezés & $\begin{array}{c}\text { Scimago minósítés } \\
2016\end{array}$ & $\begin{array}{c}\text { A megjelent } \\
\text { közlemények száma }\end{array}$ \\
\hline Journal of Cleaner Production & $Q 1$ & 6 \\
\hline Futures & Q1 & 3 \\
\hline Technological Forecasting \& Social Change & Q1 & 3 \\
\hline Applied Geography & $Q 1$ & 2 \\
\hline City, Culture and Society & Q2 & 2 \\
\hline Journal of Business Research & Q1 & 2 \\
\hline Journal of Rural Studies & Q1 & 2 \\
\hline Procedia - Social and Behavioral Sciences & - & 2 \\
\hline Cities & Q1 & 1 \\
\hline Environmental Innovation and Societal Transitions & Q1 & 1 \\
\hline International Business Review & $Q 1$ & 1 \\
\hline International Journal of Hospitality Management & Q1 & 1 \\
\hline Journal of Co-operative Organization and Management & $Q 2-Q 3$ & 1 \\
\hline Journal of Destination Marketing \& Management & Q1 & 1 \\
\hline Land Use Policy & Q1 & 1 \\
\hline Procedia Economics and Finance & - & 1 \\
\hline Tourism Management & Q1 & 1 \\
\hline
\end{tabular}

Forrás: www.sciencedirect.com; www.scimagojr.com (letöltve: 2017. október 12.) 
Lektorált tanulmányok

között publikált közleményekhez kötődik. Ha ehhez hozzátesszük, hogy a 2001-2007 periódusban mindössze 5, a 2008-2014 közöttiben 7, a kutatási paramétereknek megfelelő tanulmányt találtunk, az alig három év során napvilágot látott 20 cikk a téma iránti érdeklődés fokozott élénkülését jelzi.

Az időbeli intenzitás vizsgálata mellett a turizmus és a társadalmi innováció kapcsolatának teret adó kiadványok sajátosságait is a kutatásunk tárgyává tettük. Egyrészt feltártuk, hogy milyen diszciplináris kötődésekkel rendelkeznek azok a folyóiratok, amelyekben a kutatási kérdéseink tárgyát képező cikkek szerepelnek, másrészt ezek tudományos presztízsét is meghatároztuk. A 32 cikk 17 különbözó folyóiratban jelent meg, amelyek döntő többsége $(76 \%)$ a Scimago listán legmagasabb besorolást nyert, úgynevezett Q1-es lap, mely információ arra enged következtetni, hogy a vizsgálatunkba vont kurrens témának a legigényesebb tudományos fórumok biztosítanak platformot. A legtöbb $(6 \mathrm{db})$ cikket megjelentető folyóirat, a Journal of Cleaner Production elsősorban környezettudományi profilú, a közlemények száma alapján felállított rangsorban megosztott második Futures és Technological Forecasting $\mathcal{E}$ Social Change (3-3 db cikk) alapvetôen üzleti és menedzsment arculattal rendelkezik. A képzeletbeli dobogó harmadik helyén álló öt lap (2-2 db cikk) mindegyike meglehetôsen vegyes tematikájú, a városszociológia, a vidékfejlesztés, a marketing, a környezet, továbbá az üzlet és menedzsment tekinthető a legmarkánsabb diszciplináris kötődéseknek. Az 1-1 cikket tartalmazó lapok sorában is inkább az üzleti profilúak dominálnak, ugyanakkor a környezettudományi tematikájúak mellett felbukkannak a kifejezetten turizmussal foglalkozó kiadványok is, utóbbiak kivétel nélkül Q1 besorolásúak.

Ahogy azt már a fentiekben is megállapítottuk, a "social innovation" és a "tourism” szavak egyetlen esetben sem szerepelnek együttesen a vizsgálatba vont adatbázis közleményeinek azonosítására szolgáló legfontosabb mutatókban, vagyis a cikk címében, absztraktjában, illetve a kulcsszavaiban, ami arra enged következtetni, hogy a szimbiózis sem a kutatási kérdések, célkitúzések, sem pedig az eddig napvilágot látott eredmények vonatkozásában nem tekinthetô relevánsnak. Mindössze 11 olyan tanulmánnyal találkoztunk, ahol a "social innovation" vagy a "tourism" fogalmak szerepeltek a cikk cím, absztrakt, illetve a kulcsszó regiszterek egyikében (tehát a téma társadalmi innovációhoz vagy a turizmushoz való kötődését a szerzók markánsan megjelenítették) és a másik kifejezés a fô szövegben legalább egyszer elófordult. Az ehhez a csoporthoz tartozó tanulmányok tematikailag három részre bonthatók, a turizmusorienáltak (1), a társadalmi innováció-orientáltak (2) és a szimbiózis szempontjából irrelevánsak (3).

A turizmusorientált cikkek $(5 \mathrm{db})$ közös metszéspontja, hogy a társadalmi innováció a jövő meghatározó letéteményeseként értelmezendó, a fejlődést és a változást generáló puha tényezô. RUSSO és BORG (2002) Rotterdam várospolitikájának értékelése kapcsán kiemeli, hogy az építészet és a tudatos tervezés mellett a társadalmi innováció tekinthetô leginkább a holland kikötóvárost jellemzó agresszív modernitás meghatározó pillérének, a helyi társadalom vendégszeretete pedig megkérdójelezhetetlenül a versenyképes turisztikai termék része. FELICETTI (2016) a 2019-ben Európa Kulturális Fóvárosává avanzsáló Matera fejlesztését tárgyaló elemzésében mutat rá arra, hogy a dél-olaszországi megyeközpont a nyílt innováció részét képezó éló laboratóriumnak (living lab) tekinthetó, amely eszközként szolgál a település nemzetközi ismertségének, elismertségének társadalmi innovációra épülő biztosításához. COLE (2009) arra hívja fel a figyelmet, hogy a turizmus segíti a társadalmi együttélés alapjául szolgáló kultúrákon átíveló megértést, így az abban rejló társadalmi innovációs potenciál a jövókutatók látóterébe kerülhet. A társadalmi innováció és a turizmus jövőbeli kapcsolatának értékelésekor természetesen számításba kell venni a kockázati tényezőket is, amelyek közül RAYMAN-BACCHUS és MOLINA (2001) a foglalások és értékelések terén rohamtempóban terjedô internet alapú kommunikációban rejlô veszélyeket (például vírusok, adathalászok, kiberbúnözők), CHENG (2016) pedig a megosztó gazdaság előnyeit elszenvedők figyelembevételének fontosságát hangsúlyozza.

A társadalmi innováció-orientált cikkek $(4 \mathrm{db})$ turisztikai aspektusai szerények, ezekben a turizmus leginkább mint a szolgáltatóiparra vagy a szabadidóeltöltésre vonatkozó példaként kerül említésre. CUNHA és CUNHA (2003) Kuba gazdasági átalakulásáról írt tanulmányában a turizmust az ország húzóágazataként említik, a társadalmi innováció problematikáját a piacgazdaságra történó átállás kontextusában tárgyalják. ERIKSEN és SELBOE (2012) egy hegyvidéki gazdálkodó közösséget mutatnak be, ahol a társadalmi innováció a klímaváltozáshoz történő eredményes adaptációt szolgálja, a turizmust mint a felmelegedés következtében veszélyeztetett egyik megélhetési forrást említik. TURKER és VURAL (2017) rámutat, hogy a fejlődő országok gazdasági kihívásainak eredménytelen kezelése sok esetben a társadalmi innováció hiányára vezethetô vissza, így a tömegturizmus hatásainak kiküszöbölése sem kellóen 
hatékony. MONT, NEUVONEN és LÄHTEENOJA (2014) a turizmust a fenntartható fejlődés elvének érvényesítésével szemben álló egyik akadályként írja le. Helyi szinten életképesnek tartják a társadalmi innováció fenntarthatóságra gyakorolt hatását, azonban a globális mértékú változásokhoz már aligha elegendő.

A társadalmi innováció és a turizmus kapcsolata tekintetében a harmadik, irreleváns csoportba sorolt cikkek $(2 \mathrm{db})$ az inkluzív növekedés (HERRERA 2016) és a részvételen alapuló előrejelzés (BAS GUILLO 2015) kontextusában tárgyalják a társadalmi innováció kérdéskörét, ahol a turizmus említése periférikus.

\section{A társadalmi innováció és a turizmus metszetei}

Az a tény, hogy a nemzetközi szakirodalmat markánsan reprezentáló online adatbázisban (Sciencedirect) a keresés időszakában egyetlen egy, a társadalmi innováció és a turizmus kapcsolatát direkt módon tárgyaló folyóiratcikkel sem találkoztunk, arra enged következtetni, hogy a valóságnak nincs olyan szegmense, ahol a górcső alá vett szimbiózis létrejött volna, illetve ha létezik is ilyen, az még nem került a nemzetközi kutatások látókörébe. Véleményünk szerint a turizmusipar számos területén jelen vannak a társadalmi innováció kisebb-nagyobb csírái, de a nexus még nem lépte át a számunkra releváns értelmezési keret határait. Természetesen az sem kizárható, hogy az áttörést egy olyan kézenfekvó tény akadályozza, amely a turizmust önmagában is társadalmi innovációként tételezi fel. Ugyanis a gőzmozdonyra, mint a XIX. század vezetó technológiai innovációjára, épülő üzleti innováció (a vonalak kiépítését, összeköttetésük megteremtését, a járatok kontinentális üzemeltetését végzô társaságok létrejötte) magával vonta a társadalom szabadidő-eltöltési szokásainak megváltozását, életminőségük növelését, ezzel orvosolva egy égető problémát, a zsúfolt nagyvárosokba szorult munkásosztály környezetváltozási igényének kielégítését. Elfogadva, hogy a turizmus - makro megközelítésben - önmagában is egy, az életformát megváltoztató társadalmi innováció, szükségesnek tartjuk feltárni azokat a mikro relációkat, amelyek egyrészt a kínálat regionális, a kereslet szegmensbeli, másrészt a hatások eltérő intenzitású különbségeivel hozhatók összefüggésbe. Az alábbiakban a társadalmi innováció és a turizmus azon fontosabb, részben egymással is összefüggô metszeteit mutatjuk be, amelyek mentén az elkövetkezendôkben az elmélyültebb vizsgálatok lefolytathatók:
- Öregedés ${ }^{12}$ : a fejlett társadalmak egyik legnagyobb kihívása a népesség elöregedése, vagyis az idóskorúak részarányának, a fiatalabb generáció rovására történô fokozatos eltolódása (ILLÉS 2013). Miközben a születéskor várható élettartam és az egészségben megélt életévek száma növekszik, addig a születések és a halálozások száma csökken, amelynek egyenes következménye, hogy egyre kevesebb gyermek és egyre több idős él az adott populációban. A munkával töltött aktív évek száma és - a technológiai innovációknak köszönhetően - azok intenzitása növekszik, a nyugdíjkorhatár kitolódik, amelynek rendkívül összetett hatásai közül a nagyszülố szerep módosulása, a nyugdíjasoknak a munkaerőhiány kezelésében betöltött funkciója és az idősek szabadidő-eltöltési trendjei tekinthetőek a társadalmi innováció turizmusban való megjelenését reprezentáló kulcs mozzanatoknak (NIKITINA VORONTSOVA 2015, TIAGO et al. 2016).

- Szegénység ${ }^{13}$ : a termelés hatékonyságának olcsó munkaerőre épító növelése, az ICT ${ }^{14}$ alapú, a tercier és a kvaterner szektorra alapozó dinamikus gazdasági növekedés együtt jár a társadalom polarizációjával, a tôke koncentrációjával, a leszakadók középosztálytól való intenzív távolodásával. Mivel a turizmus is egyre inkább képzett munkaerôt igényel, az iskolázottság kulcsfontosságú a versenyképes szolgáltatások biztosításában, ezért a tanulásból való kiszorulás még a hagyományosan élőmunka-igényes szálloda- és vendéglátóipari álláshelyek betöltésének esélyeit is csökkenti (ZAGONARI 2009). Az anyagi nehézségekkel küszködőknek a szabadidôs szolgáltatásokhoz, különösen az utazáshoz való hozzáférése is korlátozott, azonban a piaci részvételük több tekintetben (keresletélénkítés, életminőség növelés, szocializáció) is rendkívül kívánatos lenne. A nyomor vagy a nyomorból való kilábalás kreatív megoldásai ideig-óráig turisztikai attrakcióként is értelmezhetők, a nyomor felszámolása azonban, ahogyan az érintettek munka világába való be-, illetve visszavezetése, továbbá az érintetteknek a turisztikai szolgáltatások fogyasztóiként történő megjelenítése elősegíthetô a társadalmi innovációval (HALL 2007).

\footnotetext{
${ }^{12}$ Az általános nemzetközi trendeket lásd: OECD (2015): Ageing debate the issues. OECD Insights, OECD Publishing, Paris (edited: Patrick Love).

${ }^{13} \mathrm{Az}$ általános nemzetközi trendeket lásd: OECD (2015): Income Inequality-The gap between rich and poor. OECD Publishing, Paris (Brian Keely). ${ }^{14}$ ICT informatikai és kommunikációs technológiai szektor
} 
Lektorált tanulmányok

- Akadálymentesség ${ }^{15}$ : az esélyegyenlóség elvének biztosításában az akadálymentes környezet megteremtése és fenntartása elsődleges feladatnak tekinthetó. Az akadálymentesség értelmezésének kitágítása, fontosságának társadalmi fel- és elismertetése, legalább olyan fokú misszió, mint az érintettek mindennapi nehézségeinek gyakorlati áthidalása. A mozgásukban, látásukban, hallásukban, táplálkozásukban vagy az óket körbe vevő mikrovilág megértésében kihívásokkal szembesülőket az utazással párosuló környezetváltozás különös megpróbáltatások elé állítja (DARCY - DICKSON 2009). Ezek leküzdésében a fizikai környezet akadályainak megszüntetése és a társadalom attitúdjének javítása egyaránt kulcsfontosságú. Talán az akadálymentesség problematikája tekinthetô a turizmus és a társadalmi innováció eredményes szimbiózisát leghatékonyabban erósítő, kutatásokkal és jó gyakorlatokkal egyaránt alátámasztható témájának.

\section{Következtetések}

A tudományos beágyazódását tekintve számos megpróbáltatással szembenézó társadalmi innováció kifejezés turizmusorientált kontextusának kialakítása a nemzetközi és a hazai kutatások fehér foltjai közé tartozik. Sem a társadalmi innovációval, sem pedig a turizmussal foglalkozó kutatói közösségek nem ismerték még fel, illetve nem aknázták még ki a témák szimbiózisában rejlő tudományos potenciált. A kézenfekvőnek túnő nexus elhomályosításában minden bizonnyal közrejátszott az a tény, hogy magának a turizmusiparnak a szabadiós szolgáltatások rendszerében történő megjelenése és dinamikus fejlődése önmagában is társadalmi innovációnak tekinthetó. Az sem igazán segítette elő a kézfogót, hogy a társadalmi innováció kifejezés meghonosodását az „"üzleti innováció hozadéka” szemléletmód hosszú idôn keresztül determinálta. A legkülönbözőbb közösségek problémáinak megoldását az életminőség növelésén keresztül elősegítő, úgynevezett kívánatos beavatkozások, illetve akciók korszerú megközelítésbe helyezték a társadalmi innováció értelmezését. Ebben a konstrukcióban már a turizmustudomány transzdiszciplináris (holisztikus látásmódú) múhelyei is könnyebben rátalálhatnak azokra az illeszkedési pontokra, amelyek mindkét pillér stabilitását erôsítik. Mivel a turizmus fejlődésének egyik legfőbb letéteményese az utazók és a

\footnotetext{
${ }^{15} \mathrm{Az}$ általános nemzetközi trendeket lásd: OECD (2003): Transforming disability into ability. Policies to promote work and income security for disabled people. OECD Publications Service, Paris.
}

célterületen lakók életminőségének növelése, ezért minden olyan vívmány, amely a két érintett közösség kölcsönös megelégedettségét szolgálja, a turizmus társadalmi innovációjaként értelmezhetô. Természetesen nem szabad megfeledkeznünk arról, hogy a társadalmi innováció feltételezi a társadalmi problémákra adandó válaszok közjót szolgáló megoldását, tehát az anyagi természetú haszon (jólét) mellett vagy éppen az helyett a szubjektív életminőségben (jóllét) megragadható előnyök felmutatása is kívánatos.

Annak ellenére, hogy explicit egyetlen nemzetközi szakirodalomban sem fordul eló a társadalmi innováció turizmus kontextusú tárgyalása, egyes közelmúltban megjelent környezettudományi, üzleti és menedzsment, illetve szociológiai orientációjú publikációkban elvétve rábukkanhatunk a tárgyaltak farvízén jelentkezô, turisztikai vonatkozású kapcsolódásokra. Mivel ezen cikkek többsége magas presztízsú folyóiratokban látott napvilágot, a társadalmi innováció mint konstrukció megfeleló ágens lehet számos akut társadalmi probléma turizmus aspektusú, a nemzetközi tudományos közösségek érdeklődésére számot tartó megoldásában, illetve annak elósegítésében. Az OECD kutatóintézete évről évre a nagyközönség elé tárja azokat a társadalmilag releváns problémákat, amelyek orvoslása egyrészt a kormányok felett álló nemzetközi szervezeteknek, az egyes országok kormányzatainak, regionális és helyi önkormányzatainak, másrészt a társadalmat a legkülönbözőbb szinten reprezentáló közösségeknek a feladta. Az öregedés, a szegénység vagy az esélyegyenlőség (azon belül kitüntetetten a mobilitásban kulcstényezőnek számító akadálymentes környezet) kihívásaival való szembesülésben - a turizmusiparban rejlő kreativitásra építve - akár az utazásban való részvétel, akár a szolgáltatások biztosítása révén kidolgozhatók azok a korszerú megoldások, amelyek a társadalmi innovációt szolgálják, és egyben hozzájárulnak a globális és lokális válaszok megfogalmazásához is.

\section{Köszönetnyilvánítás}

Jelen kutatás az Európai Unió, Magyarország és az Európai Szociális Alap társfinanszírozása által biztosított forrásból az EFOP-3.6.2-16-2017-00017 azonosítójú "Fenntartható, intelligens és befogadó regionális és városi modellek" címú projekt keretében jött létre.

\section{Felhasznált irodalom}

ABONYINÉ PALOTÁS J. (2004): Az infrastruktúra fogalma és tartalma az egyetemi hallgatók 
értelmezésében. Földrajzi Értesitô. 53(3-4). pp. 336-345.

BAS, E. - GUILLO, M. (2015): Participatory foresight for social innovation. FLUX-3D method (Forward Looking User Experience), a tool for evaluating innovations. Technological Forecasting E Social Change. 101. pp. 275-290.

BEHRINGER ZS. - KISS K. - RÁTZ T. - TÖRÖK L. (2002): A turizmus mint gazdasági, társadalmi rendszer. In: Török L. - Behringer Zs. (szerk.): Turizmus és vendéglátó ismeretek. Szókratész Külgazdasági Akadémia, Budapest. pp. 336-347.

BIRKNER, Z. - MÁHR, T. (2016): Interpreting innovation - in another way. Vezetéstudomány. 47(10). pp. 39-50.

BŐGEL GY. (2008): A schumpeteri „teremtő rombolás" módjai az infokommunikációs iparban. Közgazdasági Szemle. 55. április. pp. 344-360.

CAPOOR, B. (2017). A General Theory of Buzzwords: Synergistic Meta-Linguistic Paradigm Shifts. Inquiries Journal. 9(02). Retrieved from http://www.inquiriesjournal.com/a?id=1538

CHENG, M. (2016): Sharing economy: A review and agenda for future research. International Journal of Hospitality Management. 57. pp. 60-70.

CHIKÁN A. (2008): Vállalatgazdaságtan. Aula Kiadó, Budapest.

COLE, S. (2009): Tourism as future. Futures. 41. pp. 335-345.

CUNHA, M. - CUNHA, R. (2003): The interplay of planned and emergent change in Cuba. International Business Review. 12. pp. 445-459.

DARCY, S. - DICKSON, T. (2009): A Whole-of-Life Approach to Tourism: The Case for Accessible Tourism Experiences. Journal of Hospitality and Tourism Management. 16. pp. 32-44.

DRUCKER, P. (1987): Social innovation - Management's New Dimension. Long Range Planning. 20(6). pp. 29-34.

DUBY, G. (1984): A katedrálisok kora: mûvészet és társadalom 980-1420. Gondolat, Budapest.

ERIKSEN, S. - SELBOE, E. (2012): The social organisation of adaptation to climate variability and global change: The case of a mountain farming community in Norway. Applied Geography. 33. pp. 159-167.

FELICETTI, M. (2016): Cultural Innovation and Local development: Matera as a Cultural District. Procedia - Social and Behavioral Sciences. 223. pp. 614-618.

GADAMER, H. (2003): Igazság és módszer: egy filozófiai hermeneutika vázlata. Osiris, Budapest.

GERSHUNY, J. (1982): Social innovation - Change in the mode of provision of services. Futures. (December). pp. 496-516.

HALL, M. (ed.) (2007): Pro-Poor Tourism: Who Be- nefits? Perspectives on Tourism and Poverty Reduction. Channel View Publications, Clevedon.

HAVE, R. - RUBALCABA, L. (2016): Social innovation research: An emerging area of innovation studies? Research Policy. 45. pp. 1923-1935.

HEIDEGGER, M. (2007): Lét és idô. Osiris, Budapest.

HERRERA, M. (2016): Innovation for impact: Business innovation for inclusive growth. Journal of Business Research. 69. pp. 1725-1730.

HILL, E. (1975): Future-minded sociologists: social innovation. Futures. (April). pp. 174-175.

ILLÉS S. (2013): Idôskori nemzetközi migráció - magyar eset. Tullius Kiadó, Budapest.

KISS G. (2013): A szabadidô-szociológia legújabb trendjei és aktuális problémái. Idôvonat - tanulmányok a társadalomtudományok köréból. Kossuth Kiadó, Debrecen.

KISS K. (2015): Boldog boldogtalanok: életminőség a Balkán országokban. Földrajzi Közlemények. 139(4). pp. 288-301.

KSH (2016): Jelentés a turizmus és a vendéglátás 2016. évi teljesítményéról. http://www.ksh.hu/ docs/hun/xftp/idoszaki/jeltur/jeltur16.pdf, Letöltve: 2017. október 30.

LANDES, D. (1986): Az elszabadult Prométheusz: technológiai változások és ipari fejlődés Nyugat-Európában 1750-tôl napjainkig. Gondolat, Budapest.

MICHALKÓ G. (2012): Turizmológia - elméleti alapok. Akadémiai Kiadó, Budapest.

MOKSONY F. (2002): Fogalomalkotás és tudományos felfedezés: gondolatok Paul Lazarsfeld módszertani filozófiájáról. Szociológiai Szemle. 1. pp. $150-162$.

MONT, O. - NEUVONEN, A. - LÄHTEENOJA, S. (2014): Sustainable lifestyles 2050: stakeholder visions, emerging practices and future research. Journal of Cleaner Production. 63. pp. 24-32.

NIKITINA, O. - VORONTSOVA, G. (2015): Aging Population and Tourism: Socially Determined Model of Consumer Behavior in the "Senior Tourism" Segment. Procedia - Social and Behavioral Sciences. 214. pp. 845-851.

PIRENNE, H. (1983): A középkori gazdaság és társadalom története. Gondolat, Budapest.

PISKÓTI I. (2007): Innovációmarketing - marketinginnováció. Miskolci Egyetem, Miskolc.

POL, E. - VILLE, S. (2009): Social innovation: Buzz word or enduring term? The Journal of Socio-Economics. 38. pp. 878-885.

PUCZKÓ L. - RÁTZ T. (1998): A turizmus hatásai. Aula-Kodolányi, Budapest-Székesfehérvár.

PUCZKÓ L. - RÁTZ T. (2011): Social Tourism in Hungary: from Trade Unions to Cinema Tickets. Current Issues in Tourism. 14(5). pp. 459473. 
RAYMAN-BACCHUS, L. - MOLINA, A. (2001) Internet-based tourism services: business issues and trends. Futures. 33. pp. 589-605.

RUSSO, A. - BORG, J. (2002): Planning considerations for cultural tourism: a case study of four European cities. Tourism Management. 23. pp. 631-637.

SMITH, M. - DIEKMANN, A. (2017): Tourism and Wellbeing. Annals of Tourism Research. 66. September. pp. 1-13.

STEPCHENKOVA, S. (2012): Content analysis. In: Dwyer, L. - Gill, A. - Seetaram, N. (eds.): Handbook of research methods in tourism. Quantitative and qualitative approaches. Edward Elgar, Cheltenham. pp. 443-458.

SZILÁGYI J. (2006): A kreativitás mint az innováció egyik oki tényezője. Iparjogvédelmi és Szerzői Jogi Szemle. 1(6). pp. 39-52.

SZIRMAI V. (2015): Társadalmi jól-lét problémák Európában - egy versenyképesebb Európa lehetôsége. In: Szirmai V. (szerk.) A területi egyenlôtlenségektôl a társadalmi jól-lét felé. Kodolányi János Főiskola, Székesfehérvár. pp. 23-44.

THIEL, C. (1976): Mit jelent a "tudományos fogalomalkotás". Helikon Világirodalmi Figyelö. 22(4). pp. 569-590.

TIAGO, M. - COUTO, J. - TIAGO, F. - FARIA, S. (2016): Baby boomers turning grey: European profiles. Tourism Management. 54. pp. 13-22.

TURKER, D. - VURAL, C. (2017): Embedding social innovation process into the institutional context: Voids or supports. Technological Forecasting \& Social Change. 119. pp. 98-113.

UNWTO (2017): Tourism Highlights 2016. UNWTO, Madrid.

ZAGONARI, F. (2009): Balancing tourism education and training. International Journal of Hospitality Management. 28. pp. 2-9. 